\title{
Mechanisms and effectiveness of immunotherapy in patients infected with COVID-19
}

\author{
Mecanismos e eficácia da imunoterapia em pacientes infectados com COVID-19
}

Mecanismos y efectividad de la inmunoterapia en pacientes infectados por COVID-19

Allana Bandeira Carrilho ${ }^{1 *}$, Patricia Bandeira Carrilho ${ }^{1}$, Luiz Arthur Calheiros Leite ${ }^{1}$.

\begin{abstract}
Objective: To investigate the mechanism and effectiveness of immunotherapy in patients infected with COVID-19. Literature review: Inflammation for cytokines are directly associated with the development of COVID-19 and its severity, due to the cytokine storm, immunological pulmonary injury and systemic damage. When infected, the patient develops an inflammatory chain that results in a large quantity of pro-inflammatory cytokines, the cytokine storm, leading to fast development of the disease. The status of hyperinflammation and inflammatory biomarkers are essential tools to this disease prognosis. These biomarkers, complete blood count, CRP, Dimer and image test are important for diagnosis and prognosis for COVID-19 patients, which when detected and regulated early, minimize the risks of worsening the case. Final considerations: Therefore, immune suppression and anti-inflammatory drugs are eligible treatments for the cytokine storm, significantly reducing severe cases. In this way, immunomodulators that block interleukin 6 have potential to inhibit in a specific way the hyperinflammation status.
\end{abstract}

Keywords: Immunomodulators, COVID-19, Cytokines.

\section{RESUMO}

Objetivo: Investigar o mecanismo e a eficácia da imunoterapia em pacientes infectados com COVID-19. Revisão bibliográfica: A inflamação por citocinas está diretamente associada ao desenvolvimento de COVID-19 e sua gravidade, devido à tempestade de citocinas, lesão pulmonar imunológica e dano sistêmico. Ao ser infectado, o paciente desenvolve uma cadeia inflamatória que resulta em grande quantidade de citocinas pró-inflamatórias, a tempestade de citocinas, levando ao rápido desenvolvimento da doença. $O$ estado de hiperinflamação e biomarcadores inflamatórios são ferramentas essenciais para 0 prognóstico dessa doença. Esses biomarcadores, hemograma completo, PCR, dímero e teste de imagem, podem apresentar alterações características da infecção, importantes para o diagnóstico e prognóstico para pacientes com COVID-19, que quando são detectados e regulados precocemente, minimizam os riscos de piora do caso. Considerações finais: Portanto, a supressão imunológica e os medicamentos antiinflamatórios são tratamentos elegíveis para a tempestade de citocinas, reduzindo significamente os casos graves. Desta forma, imunomoduladores que bloqueiam a interleucina 6 têm potencial para inibir de forma específica o estado de hiperinflamação.

Palavras-chave: Imunomoduladores, COVID-19, Citocinas.

\section{RESUMEN}

Objetivo: Investigar los mecanismos y la eficacia de la inmunoterapia en pacientes infectados por COVID19. Revisión bibliográfica: La inflamación por citocinas está directamente asociada con el desarrollo de COVID-19 y su gravedad, debido a la tormenta de citocinas, la lesión pulmonar inmunitaria y el daño sistémico. Al infectarse, el paciente desarrolla una cadena inflamatoria que da como resultado una gran cantidad de citocinas proinflamatorias, la tormenta de citocinas, que conduce al rápido desarrollo de la enfermedad. El estado de hiperinflamación y los biomarcadores inflamatorios son herramientas fundamentales para el pronóstico de esta enfermedad. Estos biomarcadores, hemograma completo, PCR,

${ }^{1}$ Centro Universitário Cesmac, Maceió - AL. *E-mail: allanabandeira@hotmail.com 
dímero y prueba de imagen, pueden presentar cambios característicos de la infección, importantes para el diagnóstico y pronóstico de los pacientes con COVID-19, que cuando se detectan y regulan precozmente, minimizan los riesgos de agravar el caso. Consideraciones finales: Por lo tanto, los fármacos antiinflamatorios y de supresión inmunitaria son tratamientos elegibles para la tormenta de citosinas, lo que reduce significativamente los casos graves. Por tanto, los inmunomoduladores que bloquean la interleucina 6 tienen el potencial de inhibir específicamente el estado de hiperinflamación.

Palabras clave: Imunomoduladores, COVID-19, Citoquinas.

\section{INTRODUCTION}

Detected for the first time in the city of Wuhan, Hubei province, China, in December 2019, the new disease of Coronavirus 2019 (COVID-19), is a clinical syndrome caused by the etiological agent SARS-Cov2, which was discovered after the appearance of four cases of unexplainable fever and pneumonia, through genetic isolation of the vírus (XU Y, et al., 2020; PROMPETCHARA E, et al., 2020). The virus quickly spread among 47 countries with 82,294 cases and further pandemical status declared by World Health Organization (WHO). The major risk groups are elderly people, patients with cardiac disease, diabetes, hypertension, pneumopathy and immunosuppression (XU Y, et al., 2020).

The SARS-Cov-2 is an RNA virus, a member of the Coronaviridae family and the order Nidovirales, which causes broad-spectrum clinical manifestations, in general resulting in fever, cough and dyspnea. Patients with comorbidities develop interstitial pneumonia and acute respiratory insufficiency, septic shock, disseminated intravascular coagulation (DIC) and liver and renal dysfunction, which are highly lethal at this stage of the disease (MEMISH ZA, et al., 2020).

When infected, viral particles enter pneumocytes through angiotensin-converting-enzyme II (ACE2) receptors, being recognized by the alveolar macrophages and dendritic cells, and develop a cellular immune response mediated by CD4 T cells, activating plasma cells that results in immune disfunction and a cytokine storm, which leads to tissue damage, causing injuries, mainly in the lungs (PROMPETCHARA E, et al., 2020; MEMISH ZA, et al., 2020).

Cytokines are associated with the severity of COVID-19, in virtue of the increase of interleukin (IL-2, IL-6 IL-7), stimulating factors, interferon and inflammatory proteins. Hence, the lethality of the disease can be directly associated to hyperinflammation, occasioned by the virus, but this relation between the immune response to the virus and the severely of the disease remains uncertain (MEHTA P, et al., 2020; YI Y, et al., 2020; SPEZZANI V, et al., 2020; ROTHAN HA and BYRAREDDY SN, 2020). In this way, the objective of this study is to investigate the mechanisms and effectiveness of immunotherapy in patients infected with COVID19.

\section{LITERATURE REVIEW}

\section{Physiopathology of COVID-19}

Transmission occurs by direct contact and droplets spread in the environment, through coughing or sneezing of an infected individual. Recent studies have reported the presence of the virus in the feces of infected people, therefore there are possibilities of fecal-oral transmission. Until now, there is no evidence of vertical transmission, as all infected expectant mothers are undergoing cesarean section and cases of reinfection are rare (ROTHAN HA and BYRAREDDY SN, 2020; JIN Y, et al., 2020). It has been estimated that $44 \%$ of transmissions occurs before the emergence of symptoms, such as fever and cough, in the majority of cases. However, there are other related symptoms, like dyspnea, sore throat, fatigue, myalgia and vomiting (SIORDIA JAJ, 2020; VETTER P, et al., 2020).

The virus has tropism for cells with ACE receptors, which are widely expressed in alveolar epithelial cells (around $83 \%$ ), as well as in the nasal mucosa, bronchi, lungs, heart, esophagus, kidneys, stomach, liver, urinary bladder and ileus. Therefore, this consolidates the fact that pulmonary tissue, such as pneumocytes, are most affected, resulting in respiratory disorders (JIN Y, et al., 2020; SARZI-PUTTINI P, et al., 2020). 
The immunological response starts with the invasion of the virus into the airways, via nasopharynx and oropharynx, reaching the lungs. Subsequently, viral particles contact alveolar macrophages, dendritic cells and epithelial cells, which activates the inflammatory chain and releases a large amount of proinflammatory cytokines, the cytokine storm. Afterwards, cells with the antigen signal the CD4 T lymphocytes, with more release of cytokines and increase of the pulmonary inflammation process, as well as activate the cytotoxic CD8 T cells, which attack SARS-Cov-2. After the beginning of the humoral response via Th2 cells, plasmocytes are stimulated to produce anti-SARS-Cov-2 antibodies that attach to the virus and destroy them. However, with the cytokine storm and hyperinflammation, pneumopathies can occur, resulting in COVID-19, septic status and multiple organ failure (LI X, et al., 2020).

The incubation period of COVID-19 occurs within an interval between 2 and 14 days, which may vary depending on the immune system of the infected individual (SAHU KK and MISHRA AK, 2020). In immunosuppressed patients, the emergence of symptoms can be longer than that interval, with the incubation period reaching up to 20 days. In this patients, clinical manifestations can be atypical and without respiratory symptoms (ROMANELLI A and MASCOLO S, 2020).

The severity of the disease ranges from asymptomatic, mild, moderate, severe and critical. In severe cases, patients can develop COVID-19, from 8 to 12 days after the onset of symptoms (TENDA ED and ASAF MM, 2020).

\section{Epidemiology}

After the onset, in China, the new virus with its highly capacity of dissemination expanded worldwide, and the disease started to be considered a pandemic by the World Health Organization in March 2020 (SAHU KK and MISHRA AK, 2020).

At the beginning of august 2020, there were more than 19 million cases of infection around the world with 728 thousand deaths. The epicenter of the disease has moved from China, to the United States, which holds the position with over 4.9 million cases and 160 thousand deaths, followed by Brazil with 3 thousand cases and 100 thousand deaths, India with 2,2 thousand cases and 44 thousand deaths, now with 185 countries afflicted around the world (WHO, 2020). The mortality rate around the world varies from $3.4 \%$ to $10 \%$, being higher, mainly, in European countries which took longer to implement containment measures and have a more elderly population (VETTER P, et al., 2020).

Mortality rate increases with age, making elderly people those with highest risk of death. Patients who do not have pre-existing diseases present lower rates than those who have. However, a lot of the infected individuals are oligosymptomatic or asymptomatic but remain carriers, transmitting and disseminating the disease on a large scale (SUN K, et al., 2020).

\section{Diagnostic features}

In order to make the diagnosis, and to evaluate the clinical manifestations observed during physical examination and anamnesis of the suspected patient, medical exams must be done to discard other viral or respiratory diseases. In laboratorial exams, the hemogram reveals leukocytosis and neutrophilia related to the inflammatory process or bacterial co-infections, lymphopenia by error at the immune response and viral infection with possible destruction of $T$ lymphocytes, thrombocytopenia due to consumption coagulopathy linked to higher levels of D-dimer (LIPPI G and PLEBANI M, 2020).

With the progression of the disease there is a gradual increase in lactate dehydrogenase, C-reactive protein and ferritin levels due to the cytokine storm, and and increase in transaminases and decrease in albumin due to liver damage. In cases that progress to sepsis with disseminated intravascular coagulation (DIC), there is an increase of D-dimer and extended time of prothrombin due to the development of microthrombus. Morphological anomalies have been observed in patients with COVID-19, such as dysplastic myelocytes and promyelocytes, pseudo-Pelger-like anomalies due to defects in myelopoiesis, and the presence of circulating reactive lymphocytes. Another parameter that reflects the severity of COVID-19 is the index neutrophil and lymphocyte. The increase in this index is directly related to the hyperinflammation and prognosis of patients with COVID-19. Hematology tests, including platelet count, prothrombin time, D-dimer, 
and neutrophil to lymphocyte ratio can help clinicians to assess severity and prognosis of patients with COVID-19 (Table 1) (SIORDIA JAJ, et al., 2020; LIPPI G and PLEBANI M, 2020; FRATER JL, et al., 2020; YE Q, et al., 2020).

Table 1 - Prognostic Biomarkers in COVID-19 Patients.

\begin{tabular}{|l|l|}
\hline Parameter & Clinical mechanisms \\
\hline$\downarrow$ Lymphocytes & Decrease of the immune response against the virus \\
\hline$\downarrow$ Platelets & Platelet consumption \\
\hline$\uparrow$ Troponin & Cardiac compromise/organ failure \\
\hline$\uparrow$ D Dimer & Consumption coagulopathy \\
\hline $\begin{array}{l}\uparrow \text { Alanine aminotransferase (AST) and Aspartate } \\
\text { aminotransferase (ALT) }\end{array}$ & Liver compromise/organ failure \\
\hline$\downarrow$ Albumin $\uparrow$ ferritin & Renal compromise/hyperinflammation/ organ failure \\
\hline$\uparrow$ C-reactive protein (CRP) & Hyperinflammation and Cytokine storm \\
\hline$\uparrow$ Interleukin 6 (IL-6) & Hyperinflammation and Cytokine storm \\
\hline
\end{tabular}

Fonte: Lippi G and Plebani M, 2020. Data collected by Carrilho AB, et al., 2020.

Another exam that shows indicative signals of infection with COVID-19 is computerized tomography (CT) of the chest area, which in axial cuts demonstrates bilateral multifocal ground glass-like opacities, over two pulmonary lobes and with predominance in the lower lobes, which intensifies with increased extent of the disease. However, CT should not be performed as a diagnostic test, but rather to accompany the stages of the disease in its evolution. Because, some findings on tomography may suggest a high-risk case, such as architectural distortion, intrathoracic lymph node enlargement, and pleural effusions. Invasive exams, like bronchoscopy or pulmonary biopsy, should be used as a last resort and after discussion about its necessity due to high dissemination of viral infection (SIORDIA JAJ, 2020).

In clinical practice and the gold standard test for diagnosing COVID-19 infection is PCR, and serological tests do not indicate infection due to lack of sensitivity. Confirmation of the disease is best done through quick testing of blood samples by the immunochromatographic method, which detects positive IgM antibodies and negative $\mathrm{lgG}$, indicating a recent immune response from 7 days or less after the beginning of symptoms, with benefits for its practicality and quickness to detect the result in a few minutes. The confirmation of the COVID-19 infection must be done by RT-PCR serology, through the collection of material with a swab in the nasopharynx, to detect the virus and the viral load. Moreover, serological tests do not indicate infection due to lack of sensitivity, because the research and used of $\lg M$ and $\lg A$ antibodies has low sensitivity, and the presence of IgG antibodies or total antibodies has epidemiological purposes. Some patients also show with persistent IgM for more than 20 days with negative IgG, which shows the limitation of rapid and serological tests (JIN Y, et al., 2020).

\section{Immune response and Immunosuppression}

Covid-19 induces a pro-inflammatory response with an exacerbated release of cytokines, such as IL-6, which plays a central role, as a mediator of lung inflammation and fever. At high levels, interleukin 6 inhibits the initiation of the immune response through $T$ cells and dendritic cells, resulting in lung tissue damage, which is a clinical manifestation widely observed in patients with COVID-19, as well as high concentrations of IL- 6 in the blood. In addition, IL-6 is a strong inducer of C-reactive protein, which is also an observed laboratory alteration seen in disease (RUSSELL B, et al., 2020; ZHANG C, et al., 2020).

The hyperinflammation of the cytokine storm can facilitate viral replication and damage the microvascular barrier of the pulmonary alveoli, causing edema and damaging the lung parenchyma. This manifest themselves with the unexpected worsening of symptoms, such as dyspnea, noticed in the evolution from a moderate to severe state, consequently the increase of cytokines becomes a severity marker of the disease (JAMILLOUX Y, et al., 2020).

In a study conducted with 171 patients, an increase in IL-6 levels was observed with the worsening of the disease and these values were higher in patients who died. Therefore, high levels of this interleukin are probably responsible for lethal complications in COVID-19 and can be considered a risk factor for mortality (ZHOU F, et al., 2020). 
Several studies, in which the use of IL- 6 blockers in patients with COVID-19 was evaluated, claim that this treatment with immunosuppressants, is effective and brings benefits to critically ill patients who are being assisted in the intensive care unit (ICU), since the use of these antagonists potentially reduces the harmful immune response caused by SARS-coV-2 and the symptoms observed in these severe patients, such as pulmonary infiltration, lymphopenia and organ failure. (LIU B, et al., 2020; TUFAN A, et al., 2020; ZHAO M, 2020). On the other hand, the compromised immunity of patients undergoing immunosuppressive therapy may result in an increased prevalence of infections by other pathogenic microorganisms. Therefore must be used the end of the high viral load phase of COVID-19, along with antiviral treatments. (PICCHIANTI DIAMANTI A, et al., 2020).

According to studies, immunocompromised patients are more vulnerable to the infection, which in most cases can result in fatalities (RUSSELL B, et al., 2020). The vulnerability of such patients was evidenced by the high mortality risk during the Middle East Respiratory Syndrome (MeRS) outbreak, in 2015, in addition to the increased risk of infection to these patients when exposed (JAZIEH AR, et al., 2020). However, a new study done by the Korean Society of Infectious Diseases and the Korea Centers for Disease Control and Prevention (2020) analyzed the mortality of 54 patients with COVID-19, in which there were 8 immunocompromised patients (of which seven patients had cancer and one was the receptor of a kidney transplant) and this represented $14.8 \%$ of deaths in general (Table 2).

Table 2 - Immunocompromised groups that use immunosuppressors.

\begin{tabular}{|c|}
\hline - Oncological Patients \\
\hline - HIV carriers \\
\hline - Autoimmune disease carriers \\
\hline - Patients that use of corticosteroids \\
\hline - Transplant patients \\
\hline
\end{tabular}

Fonte: Russell B, et al., 2020. Data collected by Carrilho AB, et al., 2020.

The virus that triggered the outbreak in the Middle East is similar to the current pandemic and belongs to the same family. However, there is a disparity in mortality levels, since in the SARS virus, lethality was similar in groups of immunocompromised and non-immunocompromised patients.

The SARS-Cov-2, in addition to the human immunodeficiency virus (HIV), uses the humoral immune response to infect the target cell of the host, where few antibodies are capable of increasing its efficiency of replication, weakens the immunological system and reduces the body's capability of battling infections (WANG SF, et al., 2014; MONI MA and LIÒ P, 2014). In relation to COVID-19 and HIV, a study which evaluated 5 immunocompromised patients with HIV, of which four were suppressed virologically, found that they developed issues, infections in the upper respiratory tract and viral pneumonia, but none progressed to death (BLANCO JL, et al., 2020).

According to OGIMI C, et al. (2019), who evaluated 1237 patients and compared the clinical conditions characteristic from COVID-19 between immunocompromised and non-immunocompromised children, it was found that respiratory co-pathologies were detected more commonly in the non-immunocompromised group, as well as infections in the upper respiratory tract and the presence of fever. Nonetheless, infections of the lower respiratory tract did not differ between the groups.

According to another study, an immunocompromised patient with cancer had her chemotherapy suspended after manifestation of fever and being diagnosed with pneumonia due to SARS CoV-2 infection, presenting significant leukopenia $\left(1.300 / \mathrm{mm}^{3}\right)$, neutropenia $\left(600 / \mathrm{mm}^{3}\right)$ and lymphopenia $\left(600 / \mathrm{mm}^{3}\right)$, indicating immunosuppression. She did not present severe complications and had a benign course of the disease, while a second, non-immunocompromised patient, to whom she was compared, had severe complications and a slower recovery (SPEZZANI V, et al., 2020).

Severe-stage to critical-stage development can result from what is known as the cytokine storm, in which hyperinflammation due to an increased immune response leads to a quick progression of the disease. This evolution is usually milder in patients who have already made use of immunosuppressors before infection 
with COVID-19, since immunomodulators reduce IL-6 levels and stabilize respiratory conditions, resulting in no need for orotracheal intubation. So, treatment for the cytokine storm is fundamental to the recovery of severe patients (GANDOLFINI I, et al., 2020; ZHANG S, et al, 2020).

Patients with COVID-19 and depletion of B cells and yet who did not develop severe complications could be related to the persistence of these cells inside secondary lymphoid organs. As a consequence, the immune response is reduced, as well as cytokines, due the lack of peripheral $B$ cells, playing a positive role for the patient and resulting in a good prognosis (NOVI G, et al., 2020).

\section{Therapeutic evidence}

All patients with severe COVID-19 should be monitored for hyperinflammation through laboratorial exams to identify who could benefit from immunosuppression. The use of glucocorticoids to treat the cytokine storm can delay the virus elimination and cause complications, therefore new therapies should be used. The therapeutic options include steroids, intravenous immunoglobulin, selective blocking of cytokines and inhibition of Janus kinase 2 (JAK-2) (Table 3) (MEHTA P, et al., 2020).

Table 3 - Immunosuppressors and inflammatory inhibitors and their therapeutic use in COVID-19.

\begin{tabular}{|l|l|l|}
\hline \multicolumn{1}{|c|}{ DRUG } & \multicolumn{1}{|c|}{ MECHANISM OF ACTION POTENTIAL USE IN COVID-19 } \\
\hline Tacrolimus (TAC) & $\begin{array}{l}\text { Immunosuppressor inhibitor of } \\
\text { calcineurin enzyme }\end{array}$ & $\begin{array}{l}\text { Reduces the activity of the immune } \\
\text { system, as well as the release of } \\
\text { cytokines, improving the radiological } \\
\text { findings. }\end{array}$ \\
\hline Tocilizumab & $\begin{array}{l}\text { Monoclonal antibody IL-6 receptor } \\
\text { antagonist, which blocks the } \\
\text { transduction of the interleukin 6 signal. }\end{array}$ & $\begin{array}{l}\text { Reduces fever, CPR levels, and } \\
\text { abnormalities in in computerized } \\
\text { tomography While it can reduce } \\
\text { inflammation, it can induce fibrosis. }\end{array}$ \\
\hline Adalimumab & $\begin{array}{l}\text { Monoclonal antibody, anti-TNF, TNF } \\
\text { receptor antagonist, one of the main } \\
\text { mediators of the inflammatory response } \\
\text { and production of cytokines. }\end{array}$ & $\begin{array}{l}\text { Reduces pulmonary abnormalities and } \\
\text { the risk of septic shock. }\end{array}$ \\
\hline Leronlimab & $\begin{array}{l}\text { Humanized monoclonal antibody } \\
\text { antagonist of CCR5 receptor on CD4 T } \\
\text { lymphocytes. }\end{array}$ & $\begin{array}{l}\text { Changes macrophage migration and the } \\
\text { production of cytokines. Additionally, } \\
\text { stops viral replication. }\end{array}$ \\
\hline Anakinra & $\begin{array}{l}\text { Antagonist of the IL-1 receptor, } \\
\text { interleukin which is also released in the } \\
\text { cytokine storm. }\end{array}$ & $\begin{array}{l}\text { It works on macrophage activation } \\
\text { syndrome of septic patients. }\end{array}$ \\
\hline $\begin{array}{l}\text { Intravenous } \\
\text { Immunoglobulin } \\
\text { (IVIG) }\end{array}$ & $\begin{array}{l}\text { Competitive blocker of the Fc receptor } \\
\text { (FcR), which prevents activation of the } \\
\text { viral connection and viral endocytosis. }\end{array}$ & $\begin{array}{l}\text { It works reducing the production of } \\
\text { inflammatory cytokines and avoids } \\
\text { severe pulmonary injuries, due to the } \\
\text { reduction of viral replication. }\end{array}$ \\
\hline $\begin{array}{l}\text { Baricitinib and } \\
\text { Ruxolitinib }\end{array}$ & $\begin{array}{l}\text { JAK inhibitor immunomodulators, } \\
\text { blocks the entry of the virus in cells. }\end{array}$ & $\begin{array}{l}\text { Limits systemic inflammatory responses, } \\
\text { reducing cytotoxic T lymphocytes and } \\
\text { increases Treg. }\end{array}$ \\
\hline
\end{tabular}

Fonte: Mehta P, et al., 2020. Data collected by Carrilho AB, et al., 2020.

IL-6, as well as other cytokines produced at high levels during the response to the viral infection in severe patients, becomes a prognostic marker of severity of pulmonary complications due to COVID-19, since it deregulates the inflammatory responses (RUSSELL B, et al., 2020). As result, interleukin 6 receptor blocking immunomodulators, such as tocilizumab, are being used to assess their therapeutic efficacy (MEHTA P, et al., 2020).

The use of tocilizumab reduces the need for admission on the intensive care and mortality, since after the use of this IL-6 blocker, laboratory findings normalize and the pulmonary lesions seen on CT regress significantly, improving respiratory function and reducing oxygen therapy. ZHANG et al, showed that there are some benefits when used immunotherapies in COVID-19 infection, with a positive impact in terms of survival and favorable prognosis. However, according to the pharmacoeconomic perspective, it is suggested the administration of these immunosuppressive drugs, in critically ill patients and with considerably high 
levels of IL-6, in order to keep the patient alive while reducing possible complications (ZHANG S, et al, 2020). Clinical trials should be performed to obtain the exact dosage to be used and the ideal time to start treatment of the disease, in order to prevent these medications from adversely affecting viral clearance or not achieving sufficient efficacy (JAMILLOUX Y, et al., 2020).

It is worth mentioning that, according to some studies, immunosuppression can have negative outcomes with coronavirus, because it contributes to the increase of susceptibility to infection, and can be related to atypical clinical presentations, with severe complications (GUERY B, et al., 2013; DHOLARIA B and SAVANI BN, 2020). Immunosuppression harms the induction of the antiviral response and can also stimulate the development of secondary bacterial infections and worsen even more the prognostic of the disease. Therefore, immunosuppressors should be associated with effective antiviral therapy to avoid an uncontrolled infection and worsening of the disease. The benefits should be carefully evaluated against the potential of compromising antimicrobial immunity (RITCHIE AI and SINGANAYAGAM A, 2020).

\section{FINAL CONSIDERATIONS}

COVID-19 is an infectious disease induced by a virus that causes imbalance in the immune system and an inflammatory cytokine storm. Patients immunosuppressed by autoimmune or oncological diseases, or who have undergone transplant surgeries and who are using corticosteroids, as well as HIV patients undergoing treatment when infected with SARS-Cov-2, usually do not have severe forms of the disease, possibly due to their decreased immune response. Another possibility is that protease inhibitors may act by preventing viral proliferation of the coronavirus. Considering that the status of hyperinflammation and inflammatory biomarkers are essential tools for the prognosis of this disease, immunosuppression and antiinflammatory drugs are potential drugs for the treatment of the cytokine storm. Thus, immunomodulators with interleukin 6 blocking have therapeutic potential to specifically inhibit the status of hyperinflammation. However, further studies are needed to assess the effectiveness of immunotherapy in patients infected with COVID-19.

\section{REFERENCES}

1. BLANCO JL, et al. COVID-19 in patients with HIV: clinical case series. The Lancet HIV. 2020.

2. DHOLARIA B, SAVANI BN. How do we plan hematopoietic cell transplant and cellular therapy with the looming COVID-19 threat? Br. J. Haematol. 2020;189(2):239.

3. FRATER JL, et al. COVID-19 and the clinical hematology laboratory. International Journal of Laboratory Hematology. 2020.

4. GANDOLFINI I, et al. COVID-19 in Kidney Transplant Recipients. American Journal of Transplantation. 2020.

5. GUERY B, et al. Clinical features and viral diagnosis of two cases of infection with Middle East Respiratory Syndrome coronavirus: a report of nosocomial transmission. The Lancet. 2013;381(9885):2265-2272.

6. JAMILLOUX Y, et al. Should we stimulate or suppress immune responses in COVID-19? Cytokine and anticytokine interventions. Autoimmunity Reviews. 2020.

7. JAZIEH AR, et al. Managing Oncology Services During a Major Coronavirus Outbreak: Lessons From the Saudi Arabia Experience. JCO Global Oncology. 2020;6:518-524.

8. JIN Y, et al. Virology, epidemiology, pathogenesis, and control of COVID-19. Viruses. 2020;12(4):372.

9. KOREAN SOCIETY OF INFECTIOUS DISEASES and KOREA CENTERS FOR DISEASE CONTROL AND PREVENTION. Analysis on 54 Mortality Cases of Coronavirus Disease 2019 in the Republic of Korea from January 19 to March 10, 2020. Journal Korean Medical Science. 2020;35(12):132.

10. LI X, et al. Molecular immune pathogenesis and diagnosis of COVID-19. Journal of Pharmaceutical Analysis. 2020;10(2):102-108.

11. LIPPI G, PLEBANI M. Laboratory abnormalities in patients with COVID-2019 infection. Clinical Chemistry and Laboratory Medicine. 2020.

12. LIU B, et al. Can we use interleukin-6 (IL-6) blockade for coronavirus disease 2019 (COVID-19)-induced cytokine release syndrome (CRS)?. Journal of Autoimmunity. 2020.

13. MEHTA P, et al. COVID-19: consider cytokine storm syndromes and immunosuppression. The Lancet. 2020;395(10229):1033-1034.

14. MEMISH ZA, et al. Middle East respiratory syndrome. The Lancet. 2020;395:1063-77.

15. MONI MA, LIÒ P. Network-based analysis of comorbidities risk during an infection: SARS and HIV case studies. BMC bioinformatics. 2014;15(1):333.

16. NOVI G, et al. COVID-19 in a MS patient treated with ocrelizumab: does immunosuppression have a protective role? Multiple Sclerosis and Related Disorders. 2020. 
17. OGIMI C, et al. Characteristics and outcomes of coronavirus infection in children: the role of viral factors and an immunocompromised state. Journal of the Pediatric Infectious Diseases Society. 2019;8(1):21-28.

18. PICCHIANTI DIAMANTI A, et al. Cytokine Release Syndrome in COVID-19 Patients, A New Scenario for an Old Concern: The Fragile Balance between Infections and Autoimmunity. International Journal of Molecular Sciences. 2020;21(9):3330.

19. PROMPETCHARA E, et al. Immune responses in COVID-19 and potential vaccines: Lessons learned from SARS and MERS epidemic. Asian Pac J Allergy Immunol. 2020;38:1-9.

20. RITCHIE AI, SINGANAYAGAM A. Immunosuppression for hyperinflammation in COVID-19: a double-edged sword? The Lancet. 2020;395(10230):1111.

21. ROMANELLI A, MASCOLO S. Immunosuppression drug-related and clinical manifestation of Coronavirus disease 2019: a therapeutical hypothesis. American Journal of Transplantation. 2020.

22. ROTHAN HA, BYRAREDDY SN. The epidemiology and pathogenesis of coronavirus disease (COVID-19) outbreak. Journal of autoimmunity. 2020;109:102433.

23. RUSSELL B, et al. Associations between immune-suppressive and stimulating drugs and novel COVID-19-a systematic review of current evidence. Ecancermedicalscience. 2020;14:1022.

24. SAHU KK, et al. COVID-2019: update on epidemiology, disease spread and management. Monaldi Archives for Chest Disease. 2020;90(1):197-205.

25. SARZI-PUTTINI P, et al. COVID-19, cytokines and immunosuppression: what can we learn from severe acute respiratory syndrome? Clinical and experimental rheumatology. 2020;38(2):337-342.

26. SIORDIA JAJ. Epidemiology and Clinical Features of COVID-19: A Review of Current Literature. Journal of Clinical Virology. 2020;127:104357.

27. SPEZZANI V, et al. Benign COVID-19 in an immunocompromised cancer patient-the case of a married couple. Swiss Medical Weekly. 2020;150(1516):20246.

28. SUN K, et al. Early epidemiological analysis of the coronavirus disease 2019 outbreak based on crowdsourced data: a population-level observational study. The Lancet Digital Health. 2020;2(4):201-208.

29. TENDA ED, ASAF MM. Diagnosing COVID-19: Did We Miss Anything?. Acta Med Indones. 2020;52(1):1-4.

30. TUFAN A, et al. COVID-19, immune system response, hyperinflammation and repurposing antirheumatic drugs. Turkish Journal of Medical Sciences. 2020;50(3):620-632.

31. VETTER P, et al. Clinical features of covid-19. BMJ. 2020;369:1470.

32. WANG SF, et al. Antibody-dependent SARS coronavirus infection is mediated by antibodies against spike proteins. Biochemical and biophysical research communications. 2014;451(2):208-214.

33. WHO. Situation report - 203. Coronavirus disease 2019 (COVID-19). 10 august 2020. Available at: https://www.who.int/docs/default-source/coronaviruse/situation-reports/20200810-covid-19-sitrep203.pdf?sfvrsn=aa050308_4

34. $\mathrm{XU} \mathrm{Y}$, et al. Clinical management of lung cancer patients during the outbreak of 2019 novel coronavirus disease (COVID-19). Chinese Journal of Lung Cancer. 2020;23(3): 136-41.

35. YE Q, et al. Cytokine Storm in COVID-19 and Treatment. Journal of Infection. 2020.

36. Yi Y, et al. COVID-19: what has been learned and to be learned about the novel coronavirus disease. International Journal of Biological Sciences. 2020;16(10):1753-66.

37. ZHANG C, et al. The cytokine release syndrome (CRS) of severe COVID-19 and Interleukin-6 receptor (IL-6R) antagonist Tocilizumab may be the key to reduce the mortality. International journal of antimicrobial agents. 2020.

38. ZHANG S, et al. Rational Use of Tocilizumab in the Treatment of Novel Coronavirus Pneumonia. Clin Drug Investig. 2020.

39. ZHAO M. Cytokine storm and immunomodulatory therapy in COVID-19: role of chloroquine and anti-IL-6 monoclonal antibodies. International Journal of Antimicrobial Agents. 2020.

40. ZHOU F, et al. Clinical course and risk factors for mortality of adult inpatients with COVID-19 in Wuhan, China: a retrospective cohort study. The lancet. 2020;395:1054-62. 